\title{
A comparison of standard thermodynamic properties and solubility data for baryte, $\mathrm{Ba}^{2+}{ }_{(\mathrm{aq})}$ and $\mathrm{SO}_{4}^{2-}{ }_{(\mathrm{aq})}$
}

\author{
B. Y. Zhen-Wu ${ }^{1,2, *}$, K. Dideriksen ${ }^{1, *}$, D. A. Belova ${ }^{1}$, P. J. RaAhauge ${ }^{2}$ and S. L. S. Stipp ${ }^{1}$ \\ 1 Nano-Science Center, Department of Chemistry, University of Copenhagen, Universitetsparken 5, \\ 2100 Copenhagen OE, Denmark \\ 2 Maersk Oil and Gas A/S, Esplanaden 50, 1263 Copenhagen K, Denmark
}

[Received 24 July 2014; Accepted 3 February 2015; Associate Editor: T. Rinder]

\section{ABSTRACT}

The thermodynamic solubility product for baryte, determined at standard conditions, from data in commonly used compilations, was compared with published experimental solubility products for baryte and with the solubility products from databases used by the PHREEQC geochemical speciation code and MultiScale, which is often used by oil companies to predict or describe baryte scaling. The values in the various databases agree well with experimental data $\left(10^{-10.05}-10^{-9.96}\right.$; Melcher, 1910 ; Neuman, 1933; Templeton, 1960; Davis and Collins, 1971; Blount, 1977; Felmy et al., 1990), which agree within uncertainty with the values presented in the compilations of Robie et al. (1979), Wagman et al. (1982), Lide (2005), Raju and Atkinson (1988), as well as Nordstrom and Munoz (1994), whose values have the least uncertainty. In solutions of $50 \%$ seawater mixed with $50 \%$ reservoir formation waters, the data predict baryte supersaturation, both at standard temperature and at the temperatures expected in the reservoir, completely consistent with field observations. This provides confidence that the Pitzer approach for activity correction and the database is valid for investigations of baryte precipitation rates in high ionic strength solutions.

KeYwords: baryte, barite, $\mathrm{BaSO}_{4}$, barium, $\mathrm{Ba}^{2+}$, sulfate, $\mathrm{SO}_{4}^{2-}$, thermodynamics, standard state, solubility, PHREEQC, MultiScale.

\section{Introduction}

BARIUM $\left(\mathrm{Ba}^{2+}\right)$ is common in silicate minerals and is released to solution during weathering (Kastner, 1999; Hanor, 2000). Sulfate $\left(\mathrm{SO}_{4}^{2-}\right)$ is the most stable and most abundant sulfur species in oxidizing environments (Ivanov, 1981). Consequently, $\mathrm{Ba}^{2+}$ and $\mathrm{SO}_{4}^{2-}$ concentrations exceed baryte $\left(\mathrm{BaSO}_{4}\right)$ solubility, resulting in its formation in a variety of environments such as in sedimentary basins, at seafloor hydrothermal vents and in anthropogenic environments (Hanor, 2000). Surface seawater is supersaturated

* E-mail:

biyun.zhen@maerskoil.com; knud@nano.ku.dk

DOI: 10.1180/minmag.2014.078.6.17 with respect to calcite (Mackenzie and Andersson, 2013) but is typically undersaturated with respect to baryte (Chow and Goldberg, 1960). Baryte approaches saturation as depth increases (Wolgemuth and Broecker, 1970). Although surface seawater is undersaturated, it often contains pelagic baryte particles, some of which are interpreted to have formed in situ, where the saturation state locally exceeds its solubility product (Hanor, 2000). The presence of baryte in sediments provides information about the geological processes that occurred during sedi-

This paper is published as part of a special issue in Mineralogical Magazine, Vol. 78(6), 2014 entitled 'Mineral-fluid interactions: scaling, surface reactivity and natural systems'. 
mentation (Griffith and Paytan, 2012) and the biogeochemical cycles that controlled concentration and behaviour (von Allmen et al., 2010). Sometimes, baryte occurs as a result of human activity, most notably during petroleum production. For oil production, seawater is often injected into reservoirs but where pore solutions contain dissolved barium, the increase in sulfate concentration that results from seawater injection, precipitates baryte (Jordan et al., 2008). Baryte scaling can completely block pore throats, decreasing permeability and in some cases, destroying the reservoir.

Several sets of thermodynamic property data for baryte and aqueous barium and sulfate have been compiled since the 1930s (Latimer et al., 1933; Helgeson, 1969; Robie et al., 1979; Wagman et al., 1982; Raju and Atkinson, 1988; Nordstrom and Munoz, 1994; Robie and Hemingway, 1995; Lide, 2005) and a number of geochemical speciation codes are also available that include databases with baryte solubility constants (Crawford, 1999). One example is the open-access computer code PHREEQC, which features its own database as well as databases from other sources (Parkhurst and Appelo, 2013). Another licensed computer code, designed specifically for predicting scaling in the oil industry, is MultiScale (Scale Consult, 2006).

TABLE 1 (contd. opposite). Summary of compiled published stadard-state thermodynamic properties for baryte $\left(\mathrm{BaSO}_{4}\right)$ and the free ions barium $\left(\mathrm{Ba}^{2+}\right)$ and sulfate $\left(\mathrm{SO}_{4}^{2-}\right)$.

\begin{tabular}{|c|c|c|c|c|c|c|}
\hline Reference & $\begin{array}{c}S^{\mathrm{o}} \\
\left(\mathrm{J} \cdot \mathrm{mol}^{-1} \mathrm{~K}^{-1}\right)\end{array}$ & $\begin{array}{c}-\mathrm{BaSO}_{4(\mathrm{~s})}- \\
\Delta H_{f}^{\mathrm{o}} \\
\left(\mathrm{kJ} \cdot \mathrm{mol}^{-1}\right)\end{array}$ & $\begin{array}{c}\Delta G_{f}^{\mathrm{o}} \\
\left(\mathrm{kJ} \cdot \mathrm{mol}^{-1}\right)\end{array}$ & $\begin{array}{c}S^{\mathrm{o}} \\
\left(\mathrm{J} \cdot \mathrm{mol}^{-1} \mathrm{~K}^{-1}\right)\end{array}$ & $\begin{array}{c}\mathrm{Ba}^{2+}(\mathrm{aq}) \\
\Delta H_{f}^{\mathrm{o}} \\
\left(\mathrm{kJ} \cdot \mathrm{mol}^{-1}\right)\end{array}$ & $\begin{array}{c}\Delta G_{f}^{\mathrm{o}} \\
\left(\mathrm{kJ} \cdot \mathrm{mol}^{-1}\right)\end{array}$ \\
\hline Helgeson (1969) & & & & $12.6^{* \mathrm{e}}$ & $-538.35^{* \mathrm{e}}$ & \\
\hline Robie et al. (1979) & $\begin{array}{l}132.21^{\mathrm{a}} \\
\pm 1.68\end{array}$ & $\begin{array}{l}-1473.19^{\mathrm{b}} \\
\pm 2.00\end{array}$ & $\begin{array}{l}-1362.19^{\mathrm{b}} \\
\pm 2.60\end{array}$ & $\begin{array}{l}9.60^{\mathrm{b}} \\
\pm 1.70\end{array}$ & $\begin{array}{l}-537.64^{\mathrm{b}} \\
\pm 0.24\end{array}$ & $\begin{array}{l}-560.74^{\mathrm{b}} \\
\pm 0.24\end{array}$ \\
\hline $\begin{array}{l}\text { Wagman et al. (1982) } \\
\text { and Lide (2005) }\end{array}$ & 132.2 & -1473.2 & -1362.2 & 9.6 & -537.64 & -560.77 \\
\hline $\begin{array}{l}\text { Raju and Atkinson } \\
\text { (1988) }\end{array}$ & $132.2^{\mathrm{b}}$ & $-1473.19^{\mathrm{b}}$ & $-1362.31^{\mathrm{b}}$ & $9.6^{\mathrm{b}}$ & $-537.71^{b}$ & $-560.93^{\mathrm{b}}$ \\
\hline $\begin{array}{l}\text { Nordstrom and Munoz } \\
\text { (1994) }\end{array}$ & $\begin{array}{l}128.6^{\mathrm{c}} \\
\pm 2.0\end{array}$ & $\begin{array}{l}-1468.3^{\mathrm{c}} \\
\pm 2.5\end{array}$ & $\begin{array}{l}-1356.3^{\mathrm{c}} \\
\pm 2.6\end{array}$ & $\begin{array}{l}8.4^{\mathrm{f}} \\
\pm 2.0\end{array}$ & $\begin{array}{l}-532.5^{\mathrm{f}} \\
\pm 2.5\end{array}$ & $\begin{array}{l}-555.4^{\mathrm{f}} \\
\pm 2.6\end{array}$ \\
\hline $\begin{array}{l}\text { Robie and Hemingway } \\
\text { (1995) }\end{array}$ & $\begin{array}{l}132.2^{\mathrm{d}} \\
\pm 1.6\end{array}$ & $\begin{array}{l}-1473.6^{\mathrm{d}} \\
\pm 2.0\end{array}$ & $\begin{array}{l}-1362.5^{\mathrm{d}} \\
\pm 2.6\end{array}$ & $\begin{array}{l}8.40^{\mathrm{f}} \\
\pm 1.00\end{array}$ & $\begin{array}{l}-532.5^{\mathrm{f}} \\
\pm 2.0\end{array}$ & $\begin{array}{l}-555.4^{\mathrm{f}} \\
\pm 2.0\end{array}$ \\
\hline
\end{tabular}

Standard state: $298.15 \mathrm{~K}, 1 \mathrm{bar}$ and assuming unit activity and 1 molal ionic strength. Reference state for elemental barium and sulfur (orthorhombic) for $\Delta H_{f}^{\mathrm{o}}$ and $\Delta G_{f}^{\mathrm{o}}$ is zero at standard state and for $S^{\mathrm{o}}$ is zero at absolute zero temperature. $S^{\mathrm{o}}$ : absolute standard molar entropy; $\Delta H_{f}^{\mathrm{o}}$ : standard enthalpy of formation; $\Delta G_{f}{ }^{\mathrm{o}}$ : standard Gibbs free energy of formation; $\Delta S_{r}{ }^{\circ}$ : change in standard entropy of the reaction; $\Delta H_{r}{ }^{\circ}$ : change in standard enthalpy of the reaction; $\Delta G_{r}{ }^{\circ}$ : change in Gibbs free energy of the reaction; log K: logarithm of the thermodynamic solubility product.

Values given in italic were calculated in the present study.

Approach a: calculated change in Gibbs free energy of the reaction using the entropy and enthalpy of the reaction: $\Delta G_{r}{ }^{\mathrm{o}}=\Delta H_{r}{ }^{\mathrm{o}}-T \Delta S_{r}^{\mathrm{o}}$, where $\Delta H_{r}{ }^{\mathrm{o}}=\Delta H_{f, \mathrm{Ba}}^{\mathrm{o}}+\Delta H_{f, \mathrm{SO}_{4}}^{\mathrm{o}}-\Delta H_{f, \mathrm{BaSO}_{4}}^{\mathrm{o}} ; \Delta S_{r}^{\mathrm{o}}=S_{\mathrm{Ba}}^{\mathrm{o}}+S_{\mathrm{SO}_{4}}^{\mathrm{o}}-S_{\mathrm{BaSO}_{4}}^{\mathrm{o}}$.

Approach $b$ : calculated change in Gibbs free energy of the reaction using formation Gibbs free energy of the reactants and the product: $\Delta G_{r}^{\mathrm{o}}=\Delta G_{f, \mathrm{Ba}}^{\mathrm{o}}+\Delta G_{f, \mathrm{SO}_{4}}^{\mathrm{o}}-\Delta G_{f, \mathrm{BaSO}_{4}}^{\mathrm{o}}$

Thermodynamic solubility of baryte was determined using: $\log \mathrm{K}=-\Delta G_{r}^{\mathrm{o}} /(\ln (10) \mathrm{R} T)$, where $T$ represents the standard temperature, $298.15 \mathrm{~K}$ and $\mathrm{R}$ is the molar gas constant, $8.3144621(75) \mathrm{J} \cdot \mathrm{mol}^{-1} \mathrm{~K}^{-1}$ (NIST, 2014).

\pm : expanded uncertainty at the $95 \%$ confidence level.

*: converted from the original data in cal $\mathrm{mol}^{-1} \mathrm{deg}^{-1}$ with a thermochemical calorie $4.184 \mathrm{~J}$.

Data from: ${ }^{\mathrm{a}}$ Kelley and King (1961); ${ }^{\mathrm{b}}$ Parker et al. (1971); ${ }^{\mathrm{c}}$ Nordstrom and Munoz (1994); ${ }^{\mathrm{d}}$ DeKock (1986);

${ }^{\mathrm{e}}$ Latimer (1952); ${ }^{\mathrm{f}}$ Busenberg and Plummer (1986); ${ }^{\mathrm{g}}$ Wagman et al. (1968); ${ }^{\mathrm{h}}$ Cox et al. (1989). 
Traditionally, the thermodynamic solubility product at standard state serves as the basis for extrapolation to other conditions. Furthermore, modelling of mineral dissolution and precipitation rates relies on equations that incorporate the difference between actual activities and those expected at equilibrium (Palandri and Kharaka, 2004). Small deviation and inconsistency in reported values for stability are often amplified when one seeks to model more complex systems. Thus, an internally consistent and accurate set of thermodynamic data is required, especially for extrapolating from standard conditions to solutions at reservoir temperature and the ionic strength of seawater or formation water.

The aims of this study were to: (1) assess published thermodynamic data for baryte and the

\section{Thermodynamic properties}

Six thermodynamic compilations that include the thermodynamic properties for baryte, free barium and sulfate ions at standard conditions (1 bar, $298.15 \mathrm{~K}$ and assuming unit activity and 1 molal ionic strength) are summarized in Table 1 (all uncertainties in this work are reported with two standard deviations). All these data sets were derived from experimental and theoretical studies, where the sources have been indicated in the table footnotes.

\section{Free barium ion, $\mathrm{Ba}^{2+}$}

The only experimental data available for the entropy of free barium is from Brown et al.

TABLE 1 (contd.).

\begin{tabular}{|c|c|c|c|c|c|c|c|c|}
\hline \multirow[b]{2}{*}{$\begin{array}{c}S^{\mathrm{o}} \\
\left(\mathrm{J} \cdot \mathrm{mol}^{-1} \mathrm{~K}^{-1}\right)\end{array}$} & \multirow[b]{2}{*}{$\begin{array}{c}\mathrm{O}_{4}^{2-} \text { (aq) } \\
\Delta H_{f}^{\mathrm{o}} \\
\left(\mathrm{kJ} \cdot \mathrm{mol}^{-1}\right)\end{array}$} & \multirow[b]{2}{*}{$\begin{array}{c}\Delta G_{f}^{\mathrm{o}} \\
\left(\mathrm{kJ} \cdot \mathrm{mol}^{-1}\right)\end{array}$} & \multirow[b]{2}{*}{$\begin{array}{c}\Delta S_{r}^{\mathrm{o}} \\
\left(\mathrm{J} \cdot \mathrm{mol}^{-1} \mathrm{~K}^{-1}\right)\end{array}$} & \multicolumn{3}{|c|}{$-\mathrm{BaSO}_{4(\mathrm{~s})}=\mathrm{Ba}^{2+}{ }_{(\mathrm{aq})}+\mathrm{SO}_{4}^{2-}$} & (aq) & \multirow[b]{2}{*}{$\log K$} \\
\hline & & & & $\begin{array}{c}\Delta H_{r}^{\mathrm{o}} \\
\left(\mathrm{kJ} \cdot \mathrm{mol}^{-1}\right)\end{array}$ & $\begin{array}{c}\Delta G_{r}^{\mathrm{o}} \\
\left(\mathrm{kJ} \cdot \mathrm{mol}^{-1}\right)\end{array}$ & $\log \mathrm{K}$ & $\begin{array}{c}\Delta G_{r}^{\mathrm{o}} \\
\left(\mathrm{kJ} \cdot \mathrm{mol}^{-1}\right)\end{array}$ & \\
\hline $20.1^{* \mathrm{~g}}$ & $-909.27 * \mathrm{~g}$ & $-744.63 * \mathrm{~g}$ & $-99.6^{*}$ & $25.7 *$ & 55.38 & -9.70 & & \\
\hline $\begin{array}{l}20.00^{\mathrm{g}} \\
\pm 1.70\end{array}$ & $\begin{array}{l}-909.27^{\mathrm{g}} \\
\pm 0.24\end{array}$ & $\begin{array}{l}-744.63^{\mathrm{g}} \\
\pm 0.24\end{array}$ & $\begin{array}{l}-102.6 \\
\pm 3.0\end{array}$ & $\begin{array}{l}26.3 \\
\pm 2.0\end{array}$ & $\begin{array}{l}56.9 \\
\pm 2.2\end{array}$ & $\begin{array}{l}-9.96 \\
\pm 0.39\end{array}$ & $\begin{array}{l}56.8 \\
\pm 2.6\end{array}$ & $\begin{array}{l}-9.95 \\
\pm 0.46\end{array}$ \\
\hline 20.1 & -909.27 & -744.53 & -102.5 & 26.3 & 56.9 & -9.97 & 56.9 & -9.97 \\
\hline $20.1^{\mathrm{b}}$ & $-909.27^{\mathrm{b}}$ & $-744.54^{\mathrm{b}}$ & -102.5 & 26.2 & 56.8 & -9.95 & 56.8 & -9.96 \\
\hline $\begin{array}{l}18.5^{\mathrm{h}} \\
\pm 0.4\end{array}$ & $\begin{array}{l}-909.3^{\mathrm{h}} \\
\pm 0.4\end{array}$ & $\begin{array}{l}-744.0^{\mathrm{h}} \\
\pm 0.4\end{array}$ & $\begin{array}{l}-101.7 \\
\pm 1.0\end{array}$ & $\begin{array}{l}26.5 \\
\pm 0.5\end{array}$ & $\begin{array}{l}56.9 \\
\pm 1.8\end{array}$ & $\begin{array}{l}-9.97 \\
\pm 0.32\end{array}$ & $\begin{array}{l}57.1 \\
\pm 1.8\end{array}$ & $\begin{array}{l}-10.00 \\
\pm 0.32\end{array}$ \\
\hline $\begin{array}{l}18.5^{\mathrm{h}} \\
\pm 0.8\end{array}$ & $\begin{array}{l}-909.3^{\mathrm{h}} \\
\pm 0.8\end{array}$ & $\begin{array}{l}-744.0^{\mathrm{h}} \\
\pm 0.8\end{array}$ & $\begin{array}{l}-105.3 \\
\pm 2.0\end{array}$ & $\begin{array}{l}31.8 \\
\pm 3.0\end{array}$ & $\begin{array}{l}62.4 \\
\pm 3.0\end{array}$ & $\begin{array}{l}-10.93 \\
\pm 0.53\end{array}$ & $\begin{array}{l}63.1 \\
\pm 3.4\end{array}$ & $\begin{array}{l}-11.05 \\
\pm 0.59\end{array}$ \\
\hline
\end{tabular}

free barium and sulfate ions at standard-state conditions and compare them with published experimental solubility data and with the solubility constants used in the databases of speciation models; and (2) to suggest the most consistent and accurate parameters for the $\mathrm{Ba}^{2+}$ $\mathrm{SO}_{4}^{2-}-\mathrm{H}_{2} \mathrm{O}$ system that can be used as a reliable starting point for geochemical speciation calculations and for predicting solubility relationships in pure systems. Finally, we used the data to predict the saturation state for sulfate minerals from solutions formed of seawater mixed with formation water, from several reservoirs where baryte scaling had been observed under field conditions.
(1936). The entropy of barium was originally obtained $\left(9.2 \mathrm{~J} \cdot \mathrm{mol}^{-1} \cdot \mathrm{K}^{-1}\right)$ from the heat of the dissolution, measured on high-purity barium chloride dihydrate utilizing high-purity solids. Later recalculations by Latimer et al. (1938) and Kelley and King (1961) derived the same value $\left(9.6 \pm 1.2 \mathrm{~J} \cdot \mathrm{mol}^{-1} \cdot \mathrm{K}^{-1}\right)$.

For the $\mathrm{Ba}^{2+}$ enthalpy of formation, two experimental values are available: Fitzgibbon et al. (1973) and Cordfunke et al. (1990). Fitzgibbon et al. determined enthalpy using calorimetry $\left(-535.3 \pm 1.7 \mathrm{~kJ} \cdot \mathrm{mol}^{-1}\right)$ in a solution of $\mathrm{Ba}^{2+}$ made from high-purity metal. Cordfunke et al. calculated the enthalpy of $\mathrm{Ba}^{2+}$ 
$\left(-534.75 \pm 1.74 \mathrm{~kJ} \cdot \mathrm{mol}^{-1}\right)$ using their measured enthalpy of formation for barium chloride as well as the thermodynamic properties for the chloride ion from Cox et al. (1989). The value $\left(-537.64 \mathrm{~kJ} \cdot \mathrm{mol}^{-1}\right)$ compiled by Parker et al. (1971) and Wagman et al. (1982) is close to the experimental data reported by Fitzgibbon et al. (1973) and Cordfunke et al. (1990).

The values for entropy and enthalpy for $\mathrm{Ba}^{2+}$ published by Helgeson (1969) were taken from Latimer (1952). These values are higher than those of the other data sets (Table 1).

Finally, a new set of thermodynamic properties for $\mathrm{Ba}^{2+}$, derived from solubility data of witherite, $\mathrm{BaCO}_{3}$, were proposed later by Busenberg and Plummer (1986). They fitted the equilibrium constant of witherite to experimental solubility data between $278 \mathrm{~K}$ and $353 \mathrm{~K}$, using recalculated thermodynamic data from carbonate species presented by Busenberg et al. (1984).

\section{Free sulfate ion, $\mathrm{SO}_{4}^{2-}$}

Based on many experimental studies, the entropy of sulfate was reported by Latimer et al. (1938; $18.4 \pm 4.2 \mathrm{~J} \cdot \mathrm{mol}^{-1} \cdot \mathrm{K}^{-1}$ ) and, later, by Cox et al. $\left(1989 ; 18.50 \pm 0.40 \mathrm{~J} \cdot \mathrm{mol}^{-1} \cdot \mathrm{K}^{-1}\right)$. These values agree within uncertainty.

The entropy of sulfate from Wagman et al. (1968) is greater than that from Cox et al. (1989) and also agrees with the above values within uncertainty.

The enthalpy of formation of sulfate from the six compilations of thermodynamic properties agrees within the uncertainty with the experimental value determined by Johnson and Sunner $\left(1963 ;-909.34 \pm 0.45 \mathrm{~kJ} \cdot \mathrm{mol}^{-1}\right)$.

\section{Baryte, $\mathrm{BaSO}_{4}$}

The only experimental data available for baryte entropy were published by Latimer et al. (1933). They used vacuum bomb calorimetry to measure the heat capacity on high-purity solids and originally obtained a value of $131.84 \pm$ $0.07 \mathrm{~J} \cdot \mathrm{mol}^{-1} \cdot \mathrm{K}^{-1}$. This value was later extrapolated to standard conditions by Kelley and King $\left(1961 ; 132.2 \pm 0.8 \mathrm{~J} \cdot \mathrm{mol}^{-1} \cdot \mathrm{K}^{-1}\right)$ using the third law of thermodynamics, which states that the entropy for a pure crystal at absolute zero temperature should be zero. Later estimates by DeKock (1986), which included Latimer et al. (1933) and higher-temperature heat-capacity measurements and considered two independent baryte formation reactions from the elemental species $\left(\mathrm{Ba}_{(\mathrm{s})}, \mathrm{O}_{2(\mathrm{~g})}, \mathrm{S}_{(\mathrm{g})}\right.$ or $\left.\mathrm{S}_{(\mathrm{s})}\right)$, resulted in the same value as that estimated by Kelley and King (1961).

For the enthalpy of baryte, the first published value is from Latimer $\left(1952 ;-1465.2 \mathrm{~kJ} \cdot \mathrm{mol}^{-1}\right)$. Parker et al. (1971) included this value in their compilation and extrapolated from high-temperature data to a standard-state value of $-1466.5 \mathrm{~kJ} \cdot \mathrm{mol}^{-1}$ but no information about newer experimental studies was provided. Later, Robie et al. (1979) and DeKock (1986) adjusted this value slightly $\left(-1473.2 \mathrm{~kJ} \mathrm{~mol}^{-1}\right)$. Recently, Majzlan et al. (2002) determined the enthalpy of formation using high-temperature oxide melt calorimetry. They obtained values for: synthetic baryte, $-1459.7 \pm 3.7 \mathrm{~kJ} \cdot \mathrm{mol}^{-1}$, Colorado natural baryte, $-1464.2 \pm 3.7 \mathrm{~kJ} \cdot \mathrm{mol}^{-1}$, and South Carolina natural baryte, $-1464.9 \pm$ $3.7 \mathrm{~kJ} \cdot \mathrm{mol}^{-1}$. Values for the two natural samples agree within uncertainty with data presented by Nordstrom and Munoz (1994).

From thermodynamic properties for the barium ion (Busenberg and Plummer, 1986) and solubility measurements, Nordstrom and Munoz (1994) obtained values $\left(S^{\mathrm{o}}\right.$ : $128.6 \mathrm{~J} \cdot \mathrm{mol}^{-1} \mathrm{~K}^{-1} ; \Delta H_{f}^{\mathrm{o}}$ : $-1468.3 \mathrm{~kJ} \cdot \mathrm{mol}^{-1}$ ) that are lower than those obtained calorimetrically $\left(S^{0}: 132.2 \mathrm{~J} \cdot \mathrm{mol}^{-1} \mathrm{~K}^{-1}\right.$; $\Delta H_{f}^{\mathrm{o}}:-1473.2 \mathrm{~kJ} \cdot \mathrm{mol}^{-1}$ ) by the other compilations from Table 1.

\section{Solubility data}

There are many values for the thermodynamic solubility product for baryte. However, some are based on recalculation from data previously published in compilations (Egorov and Titova, 1962; Sillén and Martell, 1964; Khodakovsky et al., 1966; Malinin et al., 1969; Smith and Martell, 1976; Monnin and Galinier, 1988; Kaasa, 1998), and in reports of experiments at temperatures other than 298.15 K (Uchameyshvili et al., 1966; Schulien, 1987; Jiang, 1996). The results of work at non-standard conditions are not reviewed here.

Table 2 presents the thermodynamic solubility product for baryte extrapolated to infinite dilution from solubility measurements conducted at standard temperature and pressure. Although a variety of methods has been used, the values determined $(\log \mathrm{K}:-10.05$ to -9.96$)$ are in surprisingly good agreement, where the total difference is only $19 \%$. For the more recent studies, which use more accurate techniques for determining aqueous ion concentrations, all are within the limits of experimental error. 
TABLE 2. Published experimental thermodynamic solubility product for baryte extrapolated from solubility data to standard-state conditions: 1 bar, $298.15 \mathrm{~K}$ and pure water, i.e. ionic strength (IS $=0$ ).

\begin{tabular}{|c|c|c|c|}
\hline Reference & Analytical method & $\begin{array}{l}\text { Activity coefficient } \\
\text { estimation approach }\end{array}$ & $\log \mathrm{K}$ \\
\hline Melcher (1910) & Conductivity & Pitzer ion interaction & $-10.00^{\mathrm{a}}$ \\
\hline Neuman (1933) & Conductivity & $\begin{array}{l}\text { Linear relationship between solubility } \\
\text { and square root of the ionic strength }\end{array}$ & -10.04 \\
\hline Templeton (1960) & Spectroscopy & Debye-Hückel & -9.96 \\
\hline Davis and Collins (1971) & Liquid scintillation & $\begin{array}{l}\text { Linear relationship between solubility } \\
\text { and square root of the ionic strength }\end{array}$ & -9.96 \\
\hline Blount (1977) & X-ray fluorescence & Extended Debye-Hückel & -9.98 \\
\hline Felmy et al. (1990) & ICP-AES & Pitzer ion interaction & $-10.05 \pm 0.05^{\mathrm{b}} *$ \\
\hline
\end{tabular}

${ }^{a}$ : calculated in this study using a mean activity coefficient for $\mathrm{BaSO}_{4}$ of 0.970 , which is estimated using PHREEQC

Version 3 using the Pitzer.dat.

b: accepted value derived from $\mathrm{NaClO}_{4}$ electrolyte background.

ICP-AES: Inductively coupled plasma-atomic emission spectroscopy.

*: Later documentation on the NONLIN software developed by Felmy gives uncertainties as 1 standard deviation.

We assume that the uncertainty in Felmy et al. (1990) is reported at that level.

\section{Comparison of the thermodynamic properties and solubility data}

The Gibbs free energy and the thermodynamic solubility product for baryte dissolution, $\mathrm{BaSO}_{4(\mathrm{~s})}$ $=\mathrm{Ba}^{2+}{ }_{(\mathrm{aq})}+\mathrm{SO}_{4}^{2-}{ }_{(\mathrm{aq})}$, were calculated for each compilation presented in Table 1 using two approaches: from the entropy and enthalpy data (a), and from the Gibbs free energy of formation (b). The values for baryte using both approaches, from the compilations of Robie et al. (1979), Wagman et al. (1982) and Lide (2005), Raju and Atkinson (1988) and Nordstrom and Munoz (1994) agree with each other within their uncertainty because, with the exception of the Nordstrom and Munoz (1994) compilation, they originate from the same sources. They also agree with the thermodynamic solubility product determined experimentally from solubility measurements (Fig. 1). The estimates of Helgeson (1969) are slightly higher (-9.70), whereas calculations from the data of Robie and Hemingway (1995) result in significantly lower values $(-10.93$ and -11.05$)$.

Helgeson (1969) was a pioneer in using computer modelling to estimate consistent sets of thermodynamic properties from experimental data for a large number of different elements and systems to get the overall best fits. His estimate for baryte is reasonably close to the experimental values but is still off by a quarter of an order of magnitude. Although the sulfate data from Helgeson (1969) are similar to those presented by Robie et al. (1979), he obtained a higher log K because his enthalpy estimate for barium was too high.

Robie and Hemingway (1995) attempted to improve their data by incorporating updated thermodynamic properties for $\mathrm{Ba}^{2+}$ from Busenberg and Plummer (1986), resulting in values that are lower than those reported from other work. Recently, Wolery and Sutton (2013) identified discrepancies for the barium properties between the compilations from Robie et al. (1979) and Robie and Hemingway (1995) but they did not explain the origin of the discrepancies. Robie and Hemingway (1995) did not assess the internal consistency of the data set with baryte and sulfate. Consequently, the solubility product determined from their data is lower than that of Robie et al. (1979). The solubility-data deviations are larger than those from calorimetric measurements so the uncertainty associated with the $\mathrm{Ba}^{2+}$ data reported by Robie and Hemingway (1995) is greater than that reported by Robie et al. (1979).

The compilation from Robie et al. (1979), derived from calorimetric measurements, is reliable and consistent but contains larger uncertainties than the Nordstrom and Munoz 


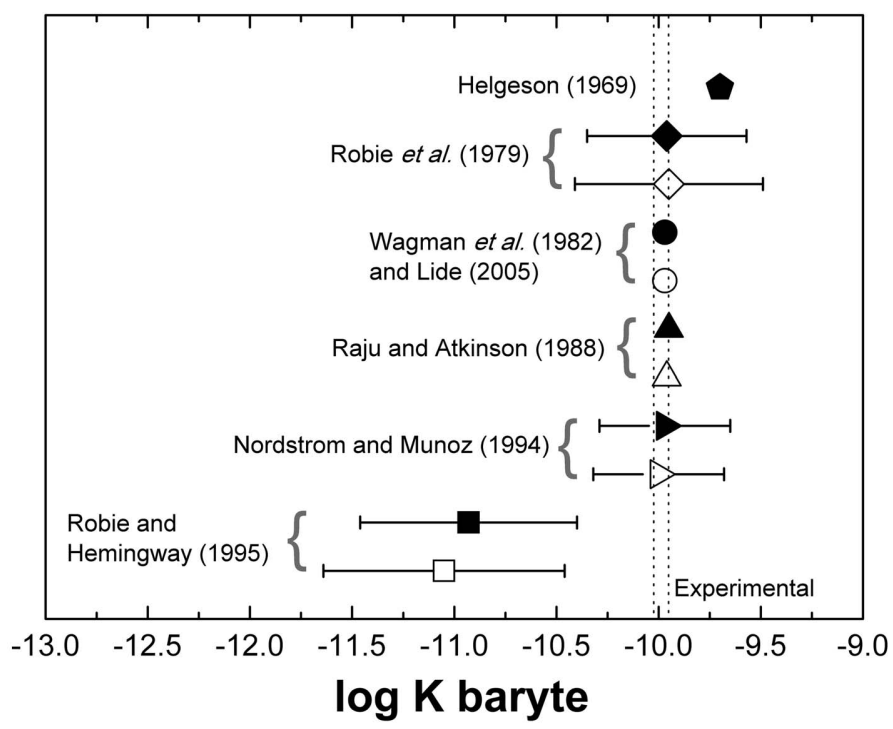

FIG. 1. Calculated $\log \mathrm{K}$ for baryte solubility at the $95 \%$ confidence limit, determined from the Gibbs free energy of reaction, derived from two approaches: (a) from enthalpy and entropy (filled symbols); and (b) from Gibbs free energy of formation (open symbols). Values from Helgeson (1969), Wagman et al. (1982), Lide (2005) and Raju and Atkinson (1988) were reported without uncertainty. The double dotted vertical bar represents the range of experimental values for the logarithm of the thermodynamic solubility product for baryte (log K: -10.05 to -9.96 ).

(1994) compilation which has also been updated with $\mathrm{Ba}^{2+}$ data from Busenberg and Plummer (1986) and the baryte data were adjusted with calculations from barium and sulfate thermodynamic properties and baryte solubility. Nordstrom and Munoz used a combination of thermodynamic data derived from a variety of experimental methods and generated a consistent data set for the baryte system after assessing the internal consistency of the newer and previously existing data.

\section{Geochemical speciation databases}

For the baryte system, eight of the nine PHREEQC databases (Parkhurst and Appelo, 2013; Version 3; i.e. amm.dat, 1lnl.dat, minteq.dat, minteq.v4.dat, phreeqc.dat, pitzer.dat, sit.dat and waterq4f.dat), include the species: $\mathrm{Ba}^{2+}, \mathrm{BaOH}^{+}, \mathrm{SO}_{4}^{2-}$ and $\mathrm{HSO}_{4}^{-}$. The database iso.dat does not include any $\mathrm{Ba}^{2+}$ species. The MultiScale database includes $\mathrm{Ba}^{2+}, \mathrm{SO}_{4}^{2-}$ and $\mathrm{HSO}_{4}^{-}$(Scale Consult, 2006; Version 8).

The origin of the thermodynamic data included in the databases for the common speciation codes is often difficult to track. For wateq $4 f$.dat, the equilibrium constant for baryte dissolution $(\log \mathrm{K}$ :
-9.97), the change in standard enthalpy of the baryte reaction $\left(\Delta H_{r}{ }^{\circ}: 26.57 \mathrm{~kJ} \cdot \mathrm{mol}^{-1}\right)$ and the analytical expression for the temperature dependence have all been adopted from Nordstrom et al. (1990), which is based on data reported by Blount (1977). Three other PHREEQC databases, amm.dat, phreeqc.dat and pitzer.dat, also use log $\mathrm{K}=-9.97$.

For 1lnl.dat, sit.dat, minteq.dat and minteq.v4.dat, it was not possible to track the origin of the baryte data. In these databases, $\log \mathrm{K}$ is similar but not the same, $-9.9711,-9.97,-9.976$ and -9.98 . The first three, llnl.dat, sit.dat and minteq.dat, have $\Delta H_{r}{ }^{\circ}$ close to $26.57 \mathrm{~kJ} \cdot \mathrm{mol}^{-1}$, presented by Nordstrom et al. (1990), with values of $25.9408 \mathrm{~kJ} \cdot \mathrm{mol}^{-1}$, $26.46 \mathrm{~kJ} \cdot \mathrm{mol}^{-1}$ and $26.28 \mathrm{~kJ} \cdot \mathrm{mol}^{-1}$. Minteq.v4.dat, however, uses a lower $\Delta H_{r}{ }^{\mathrm{o}}$ value, $23 \mathrm{~kJ} \cdot \mathrm{mol}^{-1}$. In conclusion, all of the databases associated with PHREEQC have very similar $\log \mathrm{K}$ for baryte dissolution at standard temperature but at non-standard temperature, the $\log \mathrm{K}$ using minteq.v4.dat would differ markedly. For example, at $373.15 \mathrm{~K}$, calculations with wateq 4 f.dat and minteq.v4.dat result in $\log \mathrm{K}=-9.53$ and -9.17 , respectively.

The MultiScale speciation code does not feature a specific $\log \mathrm{K}$ at $298.15 \mathrm{~K}$ for the 
baryte dissolution reaction such as those associated with PHREEQC. Rather, it uses only an analytical expression for the temperature dependence adopted from Kaasa (1998), which is based not only on data from Blount (1977) but also on data from Templeton (1960), Jiang (1996) and Malinin et al. (1969). Malinin et al. (1969) calculated a larger value $(-9.72)$ than Templeton $(1960 ;-9.96)$ even though they used the same data source. Blount (1977) pointed out that Malinin et al. (1969) overcorrected their values by changing the ion-size parameter (å) at high temperature. The empirical equation used by Kaasa (1998) is the same as PHREEQC but with different analytical coefficients. The $\log \mathrm{K}$ calculated at standard temperature using the Kaasa (1998) expression and MultiScale code results in the same value $(-9.93)$, which differs slightly from most of the data in the thermodynamic compilations (Table 1) and those produced from experiments (Table 2) but still agrees within uncertainty.

\section{Application of thermodynamic properties to other sulfate minerals}

Anhydrite $\left(\mathrm{CaSO}_{4}\right)$ is a common mineral in evaporite deposits, precipitated from highly saline brine and celestite $\left(\mathrm{SrSO}_{4}\right)$ and often coexists with baryte (Hanor, 2000). To evaluate the robustness of the data in the compilations by Robie et al. (1979) and Nordstrom and Munoz (1994), values for these minerals were calculated using the thermodynamic data for the minerals and for the free ions, $\mathrm{Ca}^{2+}$ and $\mathrm{Sr}^{2+}$. Values calculated at standard-state conditions for anhydrite, using data from Robie et al. (1979) are: log $\mathrm{K}=-4.15 \pm 0.79$, from enthalpy and entropy (a) and $\log \mathrm{K}=-4.12 \pm 0.76$ from Gibbs free energy (b). Using data from Nordstrom and Munoz (1994), these are $\log \mathrm{K}=-4.41 \pm 0.34$ from enthalpy and entropy (a) and $\log \mathrm{K}=-4.41$ \pm 0.32 from free energy (b). Calculated values for celestite, with data from Robie et al. (1979) are $\log \mathrm{K}=-6.51 \pm 0.78$, derived from a and $\log \mathrm{K}=$ $-6.46 \pm 0.70$, from $b$. With data from Nordstrom and Munoz (1994), $\log K=-6.63 \pm 0.20$ (a) and $\log \mathrm{K}=-6.63 \pm 0.26$ (b). The results agree within uncertainty with the experimental thermodynamic solubility products, for $\mathrm{CaSO}_{4}, \log \mathrm{K}=-4.62 \pm$ 0.03 and for $\mathrm{SrSO}_{4}, \log \mathrm{K}=-6.50 \pm 0.05$, which were reported by Smith and Martell (1976) and with all the PHREEQC databases for anhydrite and celestite, with one exception, i.e. the llnl.dat $(\log \mathrm{K}:-5.6771)$ for celestite. The uncertainty determined with data from the Robie et al. (1979) compilation is greater than that obtained with the data of Nordstrom and Munoz (1994).

\section{Sulfate-mineral solubility predictions in reservoir conditions}

The thermodynamic properties of the free ions and the sulfate minerals published by Nordstrom and Munoz (1994) allow us to evaluate the likelihood of precipitation from solutions where composition is known. During oil recovery, seawater, which contains sulfate, is injected into a reservoir where the formation waters often contain barium (Jordan et al., 2008). The present authors used the thermodynamic data to predict solubility for baryte, celestite and anhydrite, for a selection of reservoir fluids. We set the calculations to mix seawater with formation water in equal proportions. Figure 2 shows phase diagrams for the $\mathrm{Ba}^{2+}-\mathrm{Ca}^{2+}-\mathrm{SO}_{4}^{2-}$ and $\mathrm{Sr}^{2+}-\mathrm{Ca}^{2+}-\mathrm{SO}_{4}^{2-}$ systems using previously published data, for the temperature of the formation water as well as at standard temperature (data from Yuan et al., 1994). We also predicted solubility and plotted stability diagrams for seawater mixtures with formation water from several other producing reservoirs in the North Sea Basin. In all cases, baryte precipitation was predicted in 50:50 mixtures of seawater and formation water, in horizons where field evidence indicated baryte formation.

It is not possible to plot all of the data on one set of diagrams. For each formation water, new diagrams are required because the differences in composition and ionic strength significantly shift the solubility limits. As temperature increases, the baryte stability field decreases, whereas the fields for anhydrite and celestite increase, as expected, from the value of the $\Delta H_{r}{ }^{\mathrm{o}}$ for dissolution of these phases (Table 1). From the activities $\left(a_{x}\right)$ derived from the PHREEQC geochemical speciation program, and using the pitzer.dat database, we made diagrams to represent the mixed water for conditions where temperature was $298 \mathrm{~K}$ and above $350 \mathrm{~K}$. Figure 2 shows that the waters are highly supersaturated with respect to baryte, marginally supersaturated with respect to celestite and undersaturated with respect to anhydrite. The calculations made with the Pitzer database predict a significant thermodynamic drive for baryte precipitation when sea water mixes with forma- 

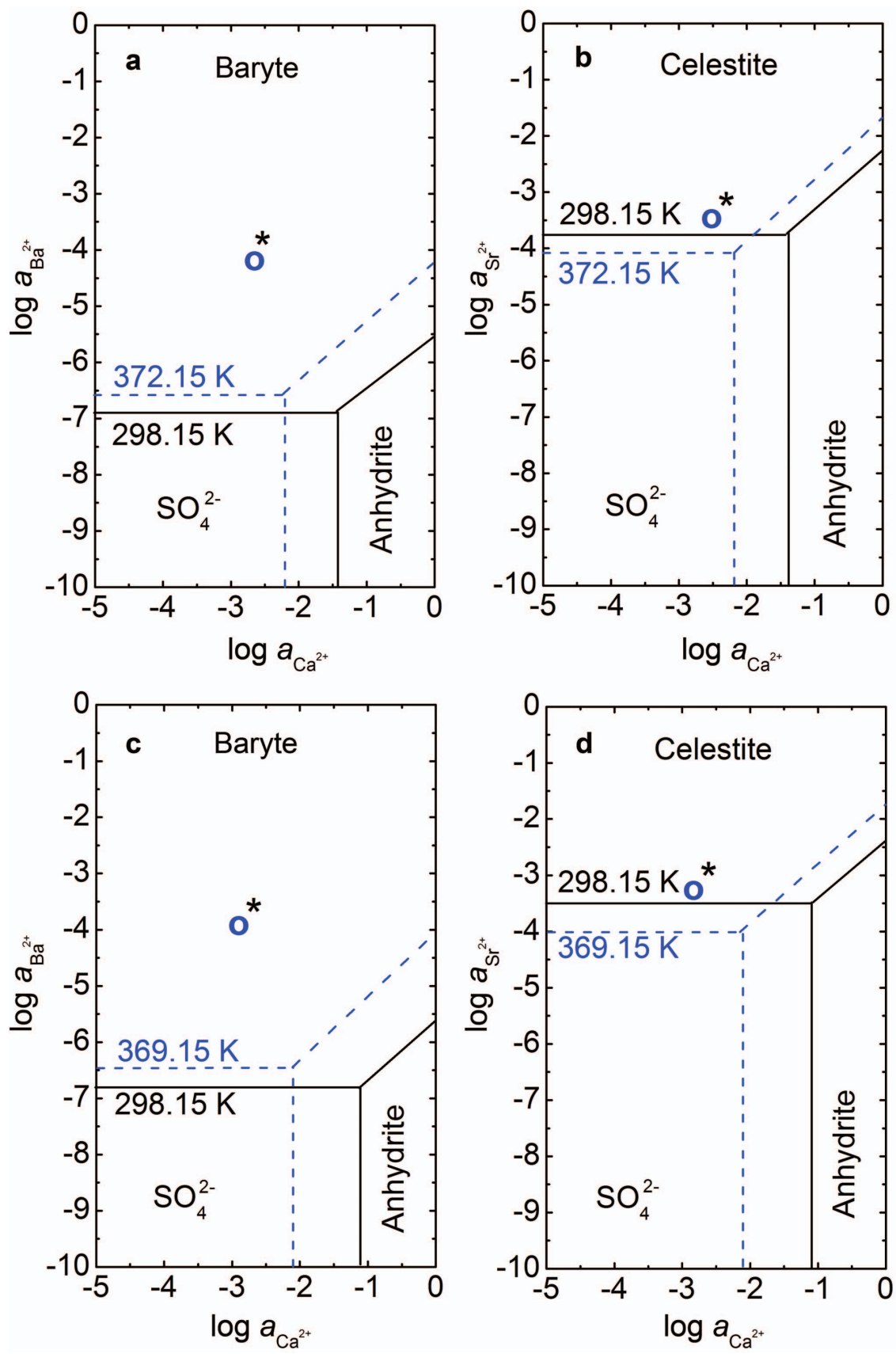

FIG. 2. Activity-activity diagram for the Beryl and Forties Field: $(a)$ The $\mathrm{Ba}^{2+}-\mathrm{Ca}^{2+}-\mathrm{SO}_{4}^{2-}$ and $(b)$ the $\mathrm{Sr}^{2+}-\mathrm{Ca}^{2+}-$ $\mathrm{SO}_{4}^{2-}$ systems at atmospheric pressure, $298.15 \mathrm{~K}$ (with $\log a_{\mathrm{SO}_{4-}^{2-}}=-3.011$ ) and $372.15 \mathrm{~K}$ (with $\log a_{\mathrm{SO}_{4-}^{-2}}=-2.975$ ) for a solution of equal portions of seawater and Beryl Field formation water. The bold star represents the mixed water composition at $298.15 \mathrm{~K}$ (c) and the blue open circle at $372.15 \mathrm{~K}$. (c) and (d) Similar diagrams for the same systems with solubility predicted for temperatures of $298.15 \mathrm{~K}$ (with $\log a_{\mathrm{SO}_{4}^{2-}}=-3.157$; bold star) and $369.15 \mathrm{~K}$ (with $\log a_{\mathrm{SO}_{4}^{2-}}=-3.088$; blue open circle) for a solution of equal portions of seawater and Forties Field formation water (data from Yuan et al., 1994). 
tion water, which is completely consistent with the field observations.

\section{Conclusions}

More recent experimental studies using modern methods for determination of aqueous concentrations report a thermodynamic solubility product for baryte of $10^{-10.05}$ to $10^{-9.96}$ at standard conditions. These values agree with those calculated from thermodynamic properties compiled by Robie et al. (1979), Wagman et al. (1982), Lide (2005), Raju and Atkinson (1988) as well as Nordstrom and Munoz (1994), whose values have the smallest uncertainty.

Thermodynamic solubility for baryte at standard conditions from PHREEQC databases: amm.dat, llnl.dat, minteq.dat, minteq.v4.dat, phreeqc.dat, pitzer.dat, sit.dat and waterq4f.dat, agrees with the more recent experimental data.

The data predict baryte precipitation when seawater is mixed with formation water from a number of reservoirs, reflecting observations in the field. This consistency of the thermodynamic data for high-salinity solutions at typical reservoir conditions indicates that the data can be combined with Pitzer calculations of activity coefficients and used for further experiments where rates of reaction will be examined.

\section{Acknowledgements}

The authors thank Maersk Oil and the DUC Partners (Danish Underground Consortium: A.P. Møller-Mærsk A/S, Shell, Chevron and the Danish North Sea Fund) for permission to publish this paper. They are grateful to the NanoGeoScience Research Section for support and encouragement and to three anonymous reviewers, whose comments considerably improved the paper. This work was funded by the European Commission (EC) 7th Framework Marie Curie (MC) Initial Training Network (ITN) grant called MINSC (Mineral Scale Formation; 290040).

\section{References}

Blount, C.W. (1977) Barite solubilities and thermodynamic quantities up to $300^{\circ} \mathrm{C}$ and 1400 bars. American Mineralogist, 62, 942-957.

Brown, O.L.I., Smith, W.V. and Latimer, W.M. (1936) The heat capacity and entropy of barium chloride dihydrate from 15 to $300^{\circ} \mathrm{K}$. The heat of solution of barium chloride dihydrate. The entropy of barium ion. Journal of the American Chemical Society, 58, $1758-1759$.

Busenberg, E. and Plummer, L.N. (1986) The solubility of $\mathrm{BaCO}_{3(\mathrm{cr})}$ (witherite) in $\mathrm{CO}_{2}-\mathrm{H}_{2} \mathrm{O}$ solutions between 0 and $90^{\circ} \mathrm{C}$, evaluation of the association constants of $\mathrm{BaHCO}_{3(\mathrm{aq})}^{+}$and $\mathrm{BaCO}_{3(\mathrm{aq})}^{\mathrm{o}}$ between 5 and $80^{\circ} \mathrm{C}$, and a preliminary evaluation of the thermodynamic properties of $\mathrm{Ba}_{\text {(aq) }}^{2+}$. Geochimica et Cosmochimica Acta, 50, 2225-2233.

Busenberg, E., Plummer, L.N. and Parker, V.B. (1984) The solubility of strontianite $\left(\mathrm{SrCO}_{3}\right)$ in $\mathrm{CO}_{2}-\mathrm{H}_{2} \mathrm{O}$ solutions between 2 and $91^{\circ} \mathrm{C}$, the association constants of $\mathrm{SrHCO}_{3}^{+}(\mathrm{aq})$ and $\mathrm{SrCO}_{3}^{0}(\mathrm{aq})$ between 5 and $80^{\circ} \mathrm{C}$, and an evaluation of the thermodynamic properties of $\mathrm{Sr}^{2+}$ (aq) and $\mathrm{SrCO}_{3}(\mathrm{cr})$ at $25^{\circ} \mathrm{C}$ and $1 \mathrm{~atm}$ total pressure. Geochimica et Cosmochimica Acta, 48, 2021-2035.

Chow, T.J. and Goldberg, E.D. (1960) On the marine geochemistry of barium. Geochimica et Cosmochimica Acta, 20, 192-198.

Cordfunke, E.H.P., Konings, R.J.M. and Ouweltjes, W. (1990) The standard enthalpies of formation of $\mathrm{MO}(\mathrm{s}), \mathrm{MCl}_{2}(\mathrm{~s})$, and $\mathrm{M}^{2+}(\mathrm{aq}, \infty)(\mathrm{M}=\mathrm{Ba}, \mathrm{Sr})$. The Journal of Chemical Thermodynamics, 22, 991-996.

Cox, J.D., Wagman, D.D. and Medvedev, V.A. (1989) CODATA (Committee on Data for Science and Technology) key values for thermodynamics. Hemisphere Republishing Corporation, New York, $271 \mathrm{pp}$.

Crawford, J. (1999) Geochemical modelling - A review of current capabilities and future directions. Swedish Environmental Protection Agency, Stockholm, Sweden, SNV Report 262, 39 pp.

Davis, J.W. and Collins, A.G. (1971) Solubility of barium and strontium sulfates in strong electrolyte solutions. Environmental Science \& Technology, 5, 1039-1043.

DeKock, C.W. (1986) Thermodynamic properties of selected metal sulfates and their hydrates. U.S. Bureau of Mines, Information Circular 9081, 59 pp.

Egorov, A.M. and Titova, Z.P. (1962) Temperature dependence of solubility products of salts with polyatomic ions. Russian Journal of Inorganic Chemistry, 7, 141-142.

Felmy, A.R., Rai, D. and Amonette, J.E. (1990) The solubility of barite and celestite in sodium sulfate: evaluation of thermodynamic data. Journal of Solution Chemistry, 19, 175-185.

Fitzgibbon, G.C., Huber, E.J. Jr. and Holley, C.E. Jr. (1973) The enthalpy of formation of barium monoxide. Journal of Chemical Thermodynamics, 5, 577-582.

Griffith, E.M. and Paytan, A. (2012) Barite in the oceanoccurrence, geochemistry and paleoceanographic applications. Sedimentology, 59, 1817-1835. 
Hanor, J.S. (2000) Barite-celestite geochemistry and environments of formation. Pp. 193-275 in: Sulfate Minerals (C.N. Alpers, J.L. Jambor and D.K. Nordstrom, editors). Reviews in Mineralogy and Geochemistry, 40. Mineralogical Society of American, Washington D.C., USA.

Helgeson, H.C. (1969) Thermodynamics of hydrothermal systems at elevated temperatures and pressures. American Journal of Science, 267, 729-804.

Ivanov, M.V. (1981) The global biogeochemical sulphur cycle. Pp. 61-78 in: Some Perspectives of the Major Biogeochemical Cycles (G.E. Likens, editor). SCOPE Report 17, John Wiley and Sons, Chichester, UK.

Jiang, C. (1996) Solubility and solubility constant of barium sulfate in aqueous sodium sulfate solutions between 0 and $80^{\circ} \mathrm{C}$. Journal of Solution Chemistry, 25, 105-111.

Johnson, W.H. and Sunner, S. (1963) The heats of solution and oxidation of sulfur oxide. Acta Chemica Scandinavica, 17, 1917-1924.

Jordan, M.M., Collins, I.R. and Mackay, E.J. (2008) Low sulfate seawater injection for barium sulfate scale control: A life-of-field solution to a complex challenge. The Society of Petroleum Engineering, SPE98096, 192-209.

Kaasa, B. (1998) Prediction of $\mathrm{pH}$, mineral precipitation and multiphase equilibria during oil recovery. Doctoral thesis, Institutt for Uorganisk Kjemi, Norges Teknisk-Naturvitenskapelige Universitet, Norway, 272 pp.

Kastner, M. (1999) Oceanic minerals: Their origin, nature of their environment, and significance. Proceedings of the National Academy of Sciences, USA, Colloquium Paper 96, 3380-3387.

Kelley, K.K. and King, E.G. (1961) Contributions to the data on theoretical metallurgy. XIV. Entropies of the elements and inorganic compounds. U.S. Department of the Interior Bureau of Mines, Bulletin 592, 149 pp.

Khodakovsky, I.L., Mishin, I.V. and Zhogina, V.V. (1966) About temperature dependence of solubility constants and some limits on the chemical composition of hydrothermal solutions. Russian Geokhimiya, $861-866$.

Latimer, W.M. (1952) The Oxidation States of the Elements and their Potentials in Aqueous Solutions, $2^{\text {nd }}$ edition. Prentice-Hall, Inc., New York, USA, 392 pp.

Latimer, W.M., Hicks, J.F.G. Jr. and Schutz, P.W. (1933) The heat capacities and entropies of calcium and barium sulfates from 15 to $300^{\circ} \mathrm{K}$. The entropy and free energy of sulfate ion. Journal of Chemical Physics, 1, 620-624.

Latimer, W.M., Pitzer, K.S. and Smith, W.V. (1938) The entropies of aqueous ions. Journal of the American
Chemical Society, 60, 1829-1831.

Lide, D.R. (editor) (2005) CRC Handbook of Chemistry and Physics, $85^{\text {th }}$ edition. CRC Press, Boca Raton, FL, USA, Tables: 5-8, 5-85 and 5-86. Online version: http://www.hbcpnetbase.com.

Mackenzie, F.T. and Andersson, A.J. (2013) The marine carbon system and ocean acidification during Phanerozoic time. Geochemical Perspectives, 2, $1-3$.

Majzlan, J., Navrotsky, A. and Neil, J.M. (2002) Energetics of anhydrite, barite, celestine, and anglesite: A high-temperature and differential scanning calorimetry study. Geochimica et Cosmochimica Acta, 66, 1839-1850.

Malinin, S.D., Uchameyshvili, N.Ye. and Khitarov, N.I. (1969) Application of the theory of strong electrolytes to the solubility of barite in aqueous metal chlorides under hydrothermal conditions. Geochemistry International, 6, 732-741.

Melcher, A.C. (1910) The solubility of silver chloride, barium sulphate, and calcium sulphate at high temperature. Journal of the American Chemical Society, 32, 50-66.

Monnin, C. and Galinier, C. (1988) The solubility of celestite and barite in electrolyte solutions and natural waters at $25^{\circ} \mathrm{C}$ : a thermodynamic study. Chemical Geology, 71, 283-296.

Neuman, E.W. (1933) Solubility relations of barium sulfate in aqueous solutions of strong electrolytes. Journal of the American Chemical Society, 55, $879-884$.

NIST (National Institute of Standard and Technology) (2014) NIST Standard Reference Database 121. NIST Physical Measurement Laboratory, U.S. Department of Commerce. Online version: http:// physics.nist.gov/cuu/index.html

Nordstrom, D.K. and Munoz, J.L. (1994) Geochemical Thermodynamics, $2^{\text {nd }}$ edition. Blackwell Scientific Publications, Boston, USA, 493 pp.

Nordstrom, D.K., Plummer, L.N., Langmuir, D., Busenberg, E., May, H.M., Jones, B.F. and Parkhurst, D.L. (1990) Revised chemical equilibrium data for major water-mineral reactions and their limitations. Pp. 398-413 in: Chemical Modeling in Aqueous Systems II (R.L Bassett and D. Melchior, editors). American Chemical Society Symposium Series 416, Washington DC.

Palandri, J.L. and Kharaka, Y.K. (2004) A compilation of rate parameters of water-mineral interaction kinetics for application to geochemical modeling. U.S. Geological Survey, Washington DC, USA, 64 pp.

Parker, V.B., Wagman, D.D. and Evans, W.H. (1971) Selected values of chemical thermodynamic properties. Tables for the alkaline earth elements. Institute for Materials Research, National Bureau of Standards, Washington DC, USA, NBS Technical 
Note 270-6, 128 pp.

Parkhurst, D.L. and Appelo, C.A.J. (2013) Description of Input and Examples for PHREEQC. Version $3-$ A Computer Program for Speciation, Batch-reaction, One-dimensional Transport, and Inverse Geochemical Calculations. U.S. Geological Survey Techniques and Methods, Book 6, Chapter A43, 497 pp. Online version: http://wwwbrr.cr.usgs.gov/projects/GWC_coupled/phreeqc

Raju, K. and Atkinson, G. (1988) Thermodynamics of scale mineral solubilities. $1 . \mathrm{BaSO}_{4}(\mathrm{~s})$ in $\mathrm{H}_{2} \mathrm{O}$ and aqueous $\mathrm{NaCl}$. Journal of Chemical and Engineering Data, 33, 490-495.

Robie, R.A. and Hemingway, B.S. (1995) Thermodynamic properties of minerals and related substances at $298.15 \mathrm{~K}$ and 1 bar $\left(10^{5}\right.$ Pascals) pressure and at higher temperatures. U.S. Geological Survey, Bulletin 2131, 470 pp.

Robie, R.A., Hemingway, B.S. and Fisher, J.R. (1979) Thermodynamic properties of minerals and related substances at $298.15 \mathrm{~K}$ and 1 bar $\left(10^{5}\right.$ Pascals) pressure and at higher temperatures. U.S. Geological Survey, Bulletin 1452, 464 pp.

Scale Consult AS (2006) MultiScale. Version 8. Trondheim, Norway. http://scaleconsult.com/index.html

Schulien, S. (1987) High-temperature/high-pressure solubility measurements in the systems $\mathrm{BaSO}_{4}$ $\mathrm{NaCl}-\mathrm{H}_{2} \mathrm{O}$ and $\mathrm{SrSO}_{4}-\mathrm{NaCl}-\mathrm{H}_{2} \mathrm{O}$ in connection with scale studies. The Society of Petroleum Engineers, SPE 16264, 233-246.

Sillén, L.G. and Martell, A.E. (1964) Stability constants of metal-ion complexes. The Royal Society of Chemistry, Special Publication No. 17, Burlington House, London, UK, 754 pp.

Smith, R.M. and Martell, A.E. (1976) Critical Stability Constants. Volume 4: Inorganic Complexes. Plenum Press, New York, USA, 257 pp.

Templeton, C.C. (1960) Solubility of barium sulfate in sodium chloride solutions from $25^{\circ}$ to $95^{\circ} \mathrm{C}$. Journal of Chemical and Engineering Data, 5, 514-516.

Uchameyshvili, N.Y., Malinin, S.D. and Khitarov, N.I. (1966) Solubility of barite in concentrated chloride solutions of some metals at elevated temperatures in relation to problems of the genesis of barite deposits. Geokhimiya (Geochemistry International), $\mathbf{1 0}$, 951-963 (1193-1205).

von Allmen, K., Böttcher, M.E., Samankassou, E. and Nägler, T.F. (2010) Barium isotope fractionation in the global barium cycle: First evidence from barium minerals and precipitation experiments. Chemical Geology, 277, 70-77.

Wagman, D.D., Evans, W.H., Parker, V.B., Halow, I., Baily, S.M. and Schumm, R.H. (1968) Selected values of chemical thermodynamic properties. Institute for Basic Standards, National Bureau of Standards, Washington DC, USA, NBS Technical Note 270-3, 264 pp.

Wagman, D.D., Evans, W.H., Parker, V.B., Schumm, R.H., Halow, I., Bailey, S.M., Churney, K.L. and Nuttall, R.L. (1982) The National Bureau of Standard (NBS) tables of chemical thermodynamic properties. Selected values for inorganic and $\mathrm{C} 1$ and C2 organic substances in SI units. Journal of Physical and Chemical Reference Data, 1, Supplement 2, $407 \mathrm{pp}$.

Wolery, T.J. and Sutton, M. (2013) Evaluation of Thermodynamic Data. Lawrence Livermore National Laboratory, USA, LLNL-TR-640133, 38 pp.

Wolgemuth, K. and Broecker, W.S. (1970) Barium in sea water. Earth and Planetary Science Letters, 8, 372-378.

Yuan, M., Todd, A.C. and Sorbie, K.S. (1994) Sulphate scale precipitation arising from seawater injection: a prediction study. Marine and Petroleum Geology, 11, 24-30. 